\title{
Extracellular Protein
}

National Cancer Institute

\section{Source}

National Cancer Institute. Extracellular Protein. NCI Thesaurus. Code C20031.

Proteins secreted out of the cell to perform a function in the extracellular medium. 